\title{
LANGUAGE POLICIES IN THE FORMER COLONIZED COUNTRIES: A COMPARATIVE STUDY
}

\author{
Diyah Ayu Rizqiani \\ Islamic University of Riau, Indonesia \\ diyah@rizqiani.com
}

\begin{abstract}
Colonialism shapes the history of a country. The language policy of a former colonized country could be seen as a mirror to see the long history of colonialism. The colonizers have strong influence in establishing the education system and language instruction used at school. In this case, language as the important element in education system could be seen as manifestation of colonialism. The language instruction in the classroom is usually the official language of the country. Some former colonized countries proudly used English as academic language. On the other hand, there are other former colonized countries which use their indigenous language as the language instruction in the classroom. By comparing these two different language policies would also give different effects to their cultural and national identity. The aims of this paper are explaining the language policies, analyzing the effect of colonialism on education system, and describing the relation between language policy and nationalism.
\end{abstract}

Keywords: language policy, colonized country, national identity.

\section{INTRODUCTION}

Colonialism inscribes the important phase in the world history. Colonialism is the result of the Second Industrial Revolution in European continent in 1870's. It is the period of a revolutionary trend in the history of mankind. The Second Industrial Revolution is also known as "the First Globalization", people can get cheaper transportation and easier communication access to travel around the world after the new invention of technology. At that time, European countries and Great Britain were advanced in technological superiority. Although European countries and Great Britain started their imperial expansion in the early of twentieth century, some European colonial empires such as British empire, French empire, Dutch, Portuguese, and Spanish were born in the fifteen and sixteen centuries which led by the great industrial powers (Aybar, 2010).

The main objective of colonialism is political domination, and another objective is the exploitation of the colonized countries (Ocheni and Nwankwo, 2012). As a consequence, colonialism gives significant impact to some aspects in colonized country. Those aspects are economic, politic, religious, and educational aspects. This paper discusses the impact of colonialism toward the educational aspect in the colonized country. This is very interesting phenomenon as stated by Flecher (2013) that the effect of colonialism in educational system are manifest in daily lives of people who live in colonial society. The effects of colonialism are learnt by each generation and are passed along the next generation. In addition, schooling is one key mechanism through which attitudes and behavior patterns are learnt.

The discussion of colonialism tends to focus on the economic exploitation of a colonized country. In fact, there is more important issue about the superiority of the colonizer's language and culture. Language reflects the nation's very basic 
identity, cultural heritage, and social pride during the colonialism period. It plays important roles in promoting and infusing nationalism among the people in the society. English spread to the colonies from England from sixteenth century. It does not only become contact language between the colonizers and the colonized, but also serve as the contact language between the colonized (Canagarajah, 2006). Therefore, English as colonized language would be the dominant language. On the other hand, the indigneous language or local language would become the minor language spoken by people in the colonized society.

The use of English for communication during colonialism period stimulates the emergence of English as lingua franca. According to Brosch (2015:74) the term lingua franca means language used for communication, it is usually used among people who do not share the same language. It is also known as the third language which is different from native or mother tongue.

Lingua franca has establised in society since colonialism period. At that time, economical and political superiority of colonizer country dominated the occupied territory. On the other word, lingua franca or it is known as "language colonization" implemented by the political dominance of the country (Armenui, 2004:274). As a consequence, the language domination brought indigenous language or vernacular language to extinction. Since lingua franca become the official language - language in business, politics, and education. There were only few people spoke the indigenous language. This condition makes the number of language speaker has declined in every generation. In this case, language policy is very needed to avoid language extinction. Language policy is considered as language planning as concerned with "both the symbolic function of language within a society, and the instrumental use that its speakers make of their language (Hoffman, 1991). In addition, Chrystal (1990) stated that language policy should be understood as systematic attempt to resolve the communication problems of a community by studying the various dialects and developing a viable policy concerning the collection and the use of different languages.

As one of the functions of lingua franca is language instruction in the classroom. Language instruction used in the classroom should reflect the national identity. The learning process must be delivered by using the indigenous language which is spoken by most of the students. In fact, the micro language planning applied differently in every country. The writer of this paper presents various language policies in the former colonized countries such as South Africa countries, former Soviet Union, Japan, China, Myanmar, and Indonesia. It is expected that the readers can figure out the effect of language policy toward nationalism and national identity.

\section{DISCUSSION}

Before discussing language policies in some former colonized countries, the writer explains various function of language. Furthermore, based on the function of language in the classroom, the writer found out that some countries used lingua franca as language instruction in the classroom and also some countries which keep using their indigenous languages for educational purposes.

\subsection{Function of Language}

Learning language means learning about the world. Language is more than communication tool, it could express thousand meanings. Gorys Keraf (1997:1) stated that language is a means of communication between members of society in the form of symbol of sound produced by human vocal organs. Fodor (1974) 
argued that language is the system of symbols and signs. The meaning of a system of symbol is a symbol which has relationship with the conventional meaning. Sign system is the relationship between sign and meaning which determined by particular characteristic of certain objects or particular situation. In addition to the definition of language, Bolinger (1981) asserted that language is the system of phonemes which formed by distinctive sound features, morpheme system, and syntax. Language is used to express meaning, so language must be in touch with outside world that is the world beyond the language includes the speakers themselves. Based on those language definitions, the writer concludes that language is a means of communication which consists of system of symbol and sign, and also system of phoneme, morpheme, and syntax.

Language is important for human communication. There are some experts proposed the function of language. Overall, there are four basic function of language as stated by Gorys Keraf (2001:3-8)

a. Self-Expression

By using language, we can express our feeling and idea. Babies cry when they are hungry. Children scream when they feel disappointed with their parents. Adults usually write their experience in diary. All of them are the expression of feeling, but adults are able to express their feeling better than baby and children because they can express with language

b. Communication

We use language as a communication tool, we already have a specific purpose. We want to be understood by others. We wanted to convey the idea that can be accepted by others. Furthermore, we want other people to buy the results of our thinking. So, in this case the reader or listener or the target audience be our primary concern. We use the language by taking into account the interests and needs of our target audience.

c. Social Integration and Social Adaptation

When we live in certain social environment, we will choose the language that will be used depending on the circumstances we face. We will use different languages for different people. We will use the non-standard language when we speak to our friends, but we use standard language when we speak to our parents or elderly people.

d. Social Control

Language is very effective for social control. It can be applied to ourselves or to the society. Information and education are delivered through language. Also, textbooks are just one example of the use of language as a means of social control.

Halliday (1975) explained that there are seven function of language, his explanation on the language function is correlated with language teaching.

a. Instrumental: language is used to communicate, show preference, choice, wants, and needs. So, people use language to solve the problems and persuade other people. In language teaching, teacher uses instrumental function of language for gathering materials and holding role play teaching activity.

b. Regulatory: language is used to take control. The teacher uses regulatory function of language for making rules in games, giving instruction, and delivering materials in the classroom.

c. Interactional: language is used to interact, plan, develop, and maintain a play or group and social activity. Teacher uses interactional function of language for structuring play, dialogue, discussion, and talking in groups. 
d. Personal: language is used to express individuality. Teacher uses personal function of language for making feeling and interacting with others.

e. Imaginative: language is used to create, explore, and entertainment. Teacher uses imaginative function of language for creating stories, dramatization, rhymes, poems, riddles, nonsense, and word play.

f. Heuristic: language is used to find things, wonder, or hypothesize. Teacher uses heuristic function of language for making question and answer, conducting inquiry and research.

g. Representational: language is used to explain. Teacher uses representational function of language for conveying massages, telling the real world, and expressing proposition.

The function of language in this paper could be seen from two different angles. First, as lingua franca, there are various functions of language such as communication, self-expression, interactional, representational, and personal function. People live in society and communicate to other people, they try to express their ideas and feelings. They want other people understand what they wants and needs. Therefore, they try to convey massages by using language.

On the other hand, language has regulatory function and social control for colonizers. They control the people by using language, they give command, create rules, express anger, and give reward by using language. In the past, the assertiveness of the colonizers could be seen from the way they ruled people in the society. One of the ways of managing people is by using language, they influence and persuade others, try to convey massages so that they could intimidate the society.

2.2 Language Policy

Language policy has become the important issue since it relates to nationalism and national identity. Language policy covers two basic aims; (1) Maximizing the ability of a population to acquire knowledge to increase educational levels and productivity. (2) Maximizing the cohesion of population to increase its ability to cooperate and promote national development. Ominiyi (2004) argued that language policy is deliberate attempt to change an individual's or community's use of language or languages or variety or varieties. Communities exist at local, regional, and International. Furhermore, Kaplan and Baldauf (1997) explained language policy is body of ideas, laws, regulations, rules, practices intended to achieve the planned change in the society, group, or system. Language policy based on Shohamy (2006) is the decision which concern the structure of language itself (corpus) and decision relating to the language use and choice (status). Similarly, Hoffman (1991) defines language policy as the symbolic function of language within a society with the instrumental use that is its speakers make of their languages. In addition to the definition of language policy, Chrystal (1990) stated that language policy is the systematic attempts to resolve the communication problems of a community by studying various dialect and its uses and developing a viable policy concerning the collection and the use of different language (Idris, 2010: 692-693).

Based on the various definitions of language policy above, the writes underlines that language policy is body of ideas, laws, laws, and regulations which concern with the structure of language and the language use and choice in order to achieve planned change in the society or country. This paper describes various language policies on education in various former colonized countries. The writer found out that some former colonized countries used lingua franca, the language of 
colonizers, as the language instruction in the classroom. On the other hand, there are some former colonized countries which use their indigenous language as the language for education.

2.3 Lingua Franca as Language Instruction in Classroom

The use of lingua franca in the classroom is closely related with the condition where there is social imbalance as a result of war, conquest, colonialism, slavery, and migration (Sankoff (2002) in Gondenzzi (2003)). In the former colonized country, the people at school community usually have different ethnical background. They need to communicate each other by sharing the same language. Some former colonized countries use English as language instruction in the classroom; the former Soviet Union, Japan, India, and Tanzania.

a. Former Soviet Union

After the dissolution of Soviet Republic in December 1991, there are fifteen new independent states that emerge from its disintegration namely Russia, Estonia, Latvia, Lithuania, Uzbekistan, Belarus, Moldova, and Ukraine. Every former Soviet Union has its own language policy which relevant to its historical background. The government use language policy as a system to prevent inter-ethnic conflict and to ensure peaceful and balanced language diversity (Lepetre (2002)). Some of the former Soviet Union use English as language instruction in the classroom, and few of them deliver the learning process by using their indigenous languages.

The language policy in former Soviet Union started in Stalin Era. In this era, the non-Russian people were allowed to keep using their native language. In order to proclaim their Soviet-ness, the government emphasized their fluency on Russian. Therefore, Russian was also known as the second mother tongue of the nonRussian people. After the reign of Stalin, there were little changes in the national language policy. The government used Russian as its official language and accepted native language as second language in daily communication. As a consequence, the number of Russian speakers declined in the former Soviet Republics. Before the ending of Soviet Union, Russian was officially become the national language (Tyson, 2009). The implementation of language policy is closely related with political issue. When the new government rules the country, there is new development in its language policy. On other word, rather than reflecting nationalism, language policy tends to resemble the political interest.

After the ruin of Soviet regime, there is an interesting social and cultural phenomenon which is called "Russification". It is non-Russian assimilation communities in order to promote Russian culture implemented in the society (Armenui, 2014). This phenomenon is also called "language decentralization". It is the condition when non-Russian have limited right to speak their native language especially in public place. On the other hand, Russian language develops rapidly since there is very significant increasing number of the speakers. Again, there is always strong relation between language policy and the history of a country. However there is disintegration in Soviet Union, Russian become undeniable language heritage. It shows social prestige and political power. Therefore, Russian becomes the national language and lingua franca replacing their native language in some former Soviet Union States.

Language policy in education also reflects the spirit of Russification. Higher education uses Russian as the national language. In fact, most of the students were overwhelmed by this condition (Tyson, 2009). The language instruction used in the classroom is different from their native language. To response to this condition, the government gives opportunity to the student to have education in their native 
language as the language instruction in the classroom, but the text books are still written in Russian. However, there are some former Soviet Union like Poland and Lithuania which keep banning the use of native language at school. The spirit of Russification at school makes young generation lose their national and also language identity.

b. Japan

Japan is considered as homogenous country. Actually there are two indigenous ethnic group namely Ainus and Okinawa. Since the Meiji Restoration promoted discriminatory assimilation policy, the minority ethnic groups are recognized as Japanese. Furthermore, Meiji restoration also brought other discrimination for minority ethnic group such as discrimination in marriage, housing and employment opportunities. The Japanese population is also dominated by foreign residents; Chinese, North and South Korean residents. As foreigners, they do not have the same right as Japanese. They do not have right to vote in the general election and also run a business. This condition make them do not enjoy as 'Japanese'. Therefore, they build their own communities which embrace their own culture and language (Hatori, 2005). Since there are various ethnic groups in Japan, we can not consider Japan as homogenous country. Meiji Restoration has eliminated its diversity. The government needs all people have the same identity as "Japanese", although this policy sacrificed their own cultural and language identities.

Kanagawa treaty in 1853 started the history of English in Japan. Since the opening of the harbor in Kobe for international trade, Western culture invaded Japan almost in every aspect in society. One of the important figure who popularized English as communication language in Japan is Arinori Mori. He was the first Japanese ambassador for America. Mori proposed English as national language in Japan, and disregarded Japanese since it was corrupted by Chinese (Joseph, 2004 in Hatori, 2005). Unfortunately, his proposal was rejected by the Minister of Education, because of the spirit of anti-Western ideology. However anti-Western sentiment remained strong until at the end of World War II, some Japanese officials recognized the value of speaking English. Unlike in Soviet Union, English was introduced in Japan by International trade. The invasion of western culture has stimulated the anti-western ideology, in which the Japanese wants to maintain their national and cultural identity by reducing the role of English in daily communication.

The new development of English language teaching in Japan started during Nationalist Era in 1922. The Japanese government invited Harold Palmer, a linguist, to conduct a reseach on language teaching. In order to conduct his research, Palmer stayed in Japan until 1936. His research critized the use of grammar-translation method in secondary school. He proposed new teaching method by using oral-aural method. After the trial in selected schools, his new language teaching method and technique was successfully accepted by Junior high School students and teachers (Hagerman, 2009). In short, Palmer's research has found out the weaknesses of English language teaching in Japan. Furthermore, his new research finding has proven to be the effective way to improve students' English language proficiency.

The Ministry of Education set up the Japan Exchange and Teaching Program (JET Program) in 1987. The aims of this program were inviting English native speakers from various English speaking countries to come to Japan. The native speakers were placed in the secondary schools around the country. However JET Program did not influence much in improving students' English proficiency, this 
program got high appreciation from the Japanese people. Japan also built pilot school for research purposes in 1992. The focus of the government research was developing language teaching method and curriculum (Hagerman, 2009). Furthermore, the most recent development in English language teaching in Japan is English has become compulsory subject in $5^{\text {th }}$ and $6^{\text {th }}$ grade in 2011. By seeing the development of language policy in Japan, we can conclude that the former government during the Japanese eras tried to isolate its country from Western influence. In fact, globalization era has forced Japan to open its country to modernization. Japanese could accept English as the International language, and also they have high respect on Japanese as their national language which is inherited and developed to the next generation.

c. India

India is multilingual country. The statistics show that India consists of 51 cities, 384 urban area, and 5161 town. Most of the Indians live in rural areas and small town with different linguistic, religious, and cultural practices. India is also rich with language diversity. Language spoken in India originate from two major linguistic families; Indo Aryan which is spoken by $74 \%$ of the total population. Also, Dravidian which is spoken by $24 \%$ of the four states in the Southern areas. In addition, other language varieties spoken in Indian originate from Austro- Asiatic and Tibeto Burman language families. Therefore, there are 1.652 dialects found in India. Because of its great degree of multilingualism in India, the country does not have mother tongue. There are 22 official languages in India. In this case, Hindi and English become the official languages which are used for official purposes in Union government of India. Moreover, the other dominant language - Tamil and Sanskrit - are classical language since 2004 (Subhash, 2013). The great diversity in ethnic group in India make the Indians live in multilingualism. Furthermore, the multilingualism does not only enrich the cultural diversity, but also embellish the linguistic diversity.

Like the country in the former Soviet Union, the history of English in India is closely related with colonialism. English came to India in $17^{\text {th }}$ century with East India Company. At that time, British ruled India after the fall of Mughal Empire the last Moslem empire in India. The role of English became more important since the establishment of British Indian Provinces namely Bengal, Madras, and Mumbai (Vanishree, 2011:317). The notion toward the importance of English was higher among merchants after the establishment of British Indian Provinces. The needs of English was getting higher after Lord Maculay - the British officer - tried to internalize English by making Indian in blood and color and English in taste, moral, intellectual, and opinion. As a consequence, English became language of Elite and intellectual due to Lord Maculay's Minute on Indian language policy in 1835 (Vijayalajshmi and Babu, 2004:2). After the arrival of British colonial, India was advanced in its international trade. Western culture was introduced to India by International trade and language. English was in high social status in society, since it was regarded as language which was claimed as the main key toward success.

Lord Macaulay's Minute in language policy gave significant effect to the development of English in Indian society. The new system of English in education developed rapidly until the independence. English was mainly studied for education and administration. In other words, the oriental education was replaced by the Western education. British has big roles in developing English education in India. British built universities which used English model educational system. Also, the Christian missionaries established high school which used English as language 
instruction in the classroom. Since the establishment of universities in India in 1857, English became first language in Indian education (Vijayalajshmi and Babu, 2004:1). After rapid establishment of schools and universities in India, it becomes a country in South Asia which is advanced in education system. On the other hand, Indians seem lose their national identity. In order to be seen as 'new elite' in the society, Indians tend to be very ambitious showing their efforts in speaking English fluently.

After India got its independence from British Colonial, English was still considered as the main language. Indian government supported the existence of both language development and language survival by enacting the language policy called "Three Language Formula". It is such a political consensus in school education (Subhash, 2013). Every student must learn three languages; mother tongue, official language of the union (English and Hindi), and foreign language. This language policy caused several problems among teachers and students. The students have difficulties in acquiring four language skills; speaking, reading, listening, and writing. Also, the teachers itself are lack of modern teaching aids and teaching technique. In addition, the presence of mixed-mother tongue students in the classroom also overwhelms the teachers. Since India is multilingual country, Indian government must reconsider the obligation for every student to learn mother tongue. Students faced difficulties to learn mother tongue at school, since it is not their daily language at home.

d. Tanzania

Tanzania is the developing country in Eastern Africa. There are 125 ethnic groups live in Tanzania. Unlike other African countries, ethnicity and religion does not have significant role in the politics of the country. Therefore, it is commonly called that ethnicity is almost invisible in Africa. The dominant population in Tanzania is mixed Arab and African descendent. The economics sector in Tanzania is supported by agriculture. It comprises crop, animal husbandry, fishery, and hunting sub-sector. As developing country, there are some social problems faced by Tanzania such as the economic failure, high rates of corruption, and presence of refugee from the neighborhood countries.

Tanzania has long period of colonialism; German era (1891-1894) and British era (1919) (Ngowi, 2009). Furthermore, colonizers have big roles in influencing language policy in Tanzania. Both German and British Colonial provided education which fit with colonialist ideology. The aims of the educational system were providing educated Africans for low-level position in the government. In addition, during Germany colonization, Swahili was promoted become official language. Also, Germany was one of the subjects which was taught at school (Swilla, 2009).

Tanzania experienced the changes in national ideology. After adopting capitalist economic system, Tanzania made significant changes in education system in 1961. The government gave more access to children to get education by abrogating school fees for secondary school in 1963. On the other hand, under socialism, Tanzania reformed the education system. Colonialized education was considered creating unequal socio economic categories among Tanzanians. Therefore, the government nationalized schools and abrogating racially and religiously separation at school. Finally, the presence political alliance in Tanzania is capitalism. It brought some changes in educational policy, the government made privatization in education in 1900's. There was great increasing number of children who enrolled to private and international school which previously restricted to expatriate children (Swilla, 2009). 
Ideology adopted by Tanzania influenced the decision of language policy and language instruction of the country. Tanzania has two official languages; English and Swahili. On other words, Tanzania adapts bilingualism education. In this case, Swahili was used as language instruction in Primary education. English was used as language instruction in Secondary, Post-Secondary education, Pre-School, and Private School. There are various reasons underlie the use of Swahili as language instruction in the classroom; cultural, historical, and nationalist spirit. Practically, Swahili is known as language for daily communication, English is used as academic language. The use of English as language instruction in the classroom stimulates dilemma and controversy. Most of students in Secondary School were lack of basic command in English. Moreover, most of the teachers also faced difficulties in finding the best type of learning theory to teach students language that neither they speak nor write (Godfrey, 2014). Another study conducted by Qorro (1999) in Marwa (2014) found out that proficiency is important factor in language instruction. In fact, Tanzania's teachers struggled with the language which they should teach in the classroom. It happened because they did not understand the language well. Therefore, joining teaching profession was one of the solutions to overcome this problem. Actually the problem in Tanzania educational system gave two big impacts. The short term impact was influencing student performance and learning ability, and the long term impact was school as educational institution produced less competent alumni.

e. Pakistan

Pakistan is an independent Islamic state on the Indian subcontinent. As part of India's independence from Great Britain in 1947, a partition took part of their land and created Pakistan as a separate Islamic nation. It is estimated that approximately 95 percent of the population are Muslim, but members of several minority religions live there, including some Hindus, Christians, Parsis, Sikhs, and Buddhists. Although the modern nation of Pakistan was but fifty-three years old in 2000, it has territorial areas and tribal populations whose histories date back many centuries; thus Pakistan has both an ancient and a relatively new identity.

Pakistan is in South Asia and is 339,697 square miles (879,815 square kilometers) in area. It was created from what had been the northwest side of India. All of the country except the southern portion is landlocked, with Afghanistan to the northwest, Jammu and Kashmir to the northeast, India to the east and southeast, and Iran to the west. In the southern portion, along the shores of the city of Karachi, which was the original capital when the nation was formed in 1947, is the Arabian Sea. There are four major ethnic groups in Pakistan: Pashtuns, Baluchis, Punjabis, and Sindhis. Pashtuns reside mainly in North West Frontier Province, and Baluchis live mostly in the Baluchistan province. Punjabis reside in the North-East, namely in the Punjab province, and Sindhis in the South-East, the Sindh province. Also, Pakistan is linguistically diverse; besides Urdu, the official language, Punjabi, Sindhi, Pashto, Baluchi, and Brahui are widely spoken.

Pakistan has no less than 25 languages (Mansoor 2005). Punjabi is spoken as a mother tongue by $44.15 \%$, Pashto by $15.42 \%$, Sindhi by $4.10 \%$, Siraiki by $10.53 \%$, Urdu by $7.57 \%$, Baluchi by $3.57 \%$, and other languages by $4.66 \%$ of the population (Census 2001). In Pakistan, the official language policy demonstrates a strong commitment to Urdu in favour of regional languages but stays ambiguous regarding the relative status of Urdu and English. Despite Urdu being declared a national language, and the lingua franca in the country, historically, it is the use of English that is pervasive in government, bureaucracy, the higher judiciary, higher education 
and almost all official business (Mansoor, 2005; Rahman, 1996). In this context, the significance of learning the two dominant languages: Urdu and English becomes highly important, with the knowledge of the latter especially related to prestige and power.

The national language is Urdu (national languages were Urdu and Bengali from 1955 until 1971, when East Pakistan became Bangladesh) though this language is, and has always been, the mother-tongue of a minority of the population of Pakistan. This minority came from India, mostly after the creation of Pakistan in 1947, and is termed Mohajir (refugee or immigrant). The rationale for this privileged status of Urdu, as given by the government of Pakistan, is that Urdu is so widely spread that it almost holds the status of being the first language of all Pakistanis. Above all, it is a symbol of unity, helping to create a unified Pakistani identity. As for the medium of instruction, the rationale is that Urdu, the most widespread urban language, is the language used in education. As English is useful in official and international language instances, it, too, is taught at the higher levels, especially to those who study science and technology.

This ongoing debate, though had little impact on the private English-medium schools which continued to function. However, in the late 1970s, the government nationalized private schools to impose Urdu as the medium of instruction in the name of national solidarity Nevertheless, the attempt failed, as even the government's own institutions, such as those run by the Ministry of Defence, resisted the change. The policy was reversed and denationalization in 1979 led to a surge of English-medium private institutions, especially in urban areas, which charged varying levels of fees. The choice of the medium of education was now left to the provincial governments. In 2002, the Punjab government initiated Englishmedium instruction for a section within selected government schools from grade VI onwards on experimental basis and further both the governments of Punjab and Sindh planned the conversion of all government schools from Urdu to Englishmedium instruction from class I onwards until 2012 ..

In higher education the policies and reports of education commissions/committees (1957-1998) declared English as the medium of instruction (Mansoor 1993). However, this has always been meant to be a shortterm arrangement until materials in Urdu could be developed. The period allocated for switching the medium of instruction from English to Urdu, in these reports ranges from 15 years in 1959 to seven years in 1982. Although the problems of students in higher education stemming from the use of English as the medium of instruction are realized (Mansoor 2005), little attention has been paid to address the issue, and more recent reports hardly mention it. At present, English is the main medium of instruction at higher education level, though there is choice to take up a limited range of subjects in Urdu, this choice narrows down with progression into higher level. All science-based subjects, especially those leading to medical or engineering degrees, are offered only in English at all government and private universities.

\subsection{Indigenous Language as National Identity}

People usually can speak more than one language in a multilingual country. The spread of language across the distance and borders may be attributed to the vast expansion of colonialism, a great movement of people from one area to the other areas, or even the influence of location and geographic proximity. There are some former colonized countries which try to maintain the existence their indigenous language. Those countries are Nigeria, Eritrea, and Botswana. Therefore, 
governments become the active agent in determining language policies which represent their cultural and national identity.

a. Nigeria

Nigeria is multicultural country in the West African continent. Geographically, Nigeria is inhibited by over 150 million people. British colonial divided the country into three areas; $29 \%$ are Hausa speaking nation located in northern region, $21 \%$ are Yoruba who lives in western region, and $18 \%$ are Igbo located in the eastern part of the country. Nigeria is a country which represents complex linguistic diversity. Nigeria does not have a national language. Based on the number of language spoken in the society, there are three main languages; Hausa, Yoruba, and Igbo (Danladi, 2013). On the other words, geographical zone in Nigeria represents language and ethnical identity. Therefore, language becomes principal source of individual identity and social-political capital for interaction across different political and cultural border (Ogunmodimu, 2015). Linguistic complexity in Nigeria is the potential capital to stimulate political and cultural conflicts. The label of majority and minority language represent the political and cultural domination. Furthermore, compared to ethnical diversity issue, linguistic diversity becomes more potential conflict in society.

The language history in Nigeria started on colonialism period. The colonizers came to Nigeria for the spirit of glory, gold, and gospel. It is believed that Portuguese was the first European language used in Nigeria. Portuguese was the communication language since Portuguese opened the sea port in Gwarto for trading. After the reign of Portuguese, English was introduced to Nigeria some period before slavery era. The first usage of English in Nigeria is the simplification of English or it is known as pidgin. Many European missionaries went to Nigeria to spread Christianity. Besides religious activity, the European missionaries had contribution in building school in Northern Nigeria where English was taught as the school subject (Danladi, 2013). The beginning of the colonial period standard interest in English started after the Amalgamation of the Northern and Southern Nigeria in 1941. As a consequence, English was used for science, math, and official usage. Also, a lot of books were produced in indigenous language. The use of indigenous language for language instruction was restricted to primary and secondary school (Adejimola, 2010).

English has dual role in Nigeria. It becomes contact language among Nigerian who do not share the same mother tongue, and also among Nigerians and Europeans. English is also considered as language of commerce, education, politics, law, and administration. Nigeria faced language policy changes. First, by early 1947, Sir Richard constitution proclaimed English as the official language in Nigeria, Hausa became the legislative language in Northern Nigeria. Then, the 1954 constitution recognized domestic and regional language. English served as national official and regional official language in the South, Hausa served as the regional language in the North Nigeria (Owolabi and Dada, 2012). The national policy on education in 1977 showed that the education system in Nigeria gave little space for the development of minority language. The primary school used Nigerian language as language instruction, and mid-primary English became the instrument. Moreover, the use of minority language in examination was conducted in some parts of Nigeria. In short, the implication of language policy in Nigeria is advocating multilingualism as the national goals. It recognized English as official language, while Hausa, Igbo, and Yoruba as potential national language. Finally, all 
Nigerians language becomes language instruction in initial literacy and non-formal education (Adejimola, 2010).

b. Eritrea

Eritrea was formerly the northernmost of Ethiopia province. The name Eritrea derives from the word "Sinus Erythraeus". It was given by the Greek tradesman for the body of water between Arabian Peninsula and African Continent. During the Roman Empire, Eritrea was called "Mare Erythraeum" means "The Red Sea". The name "Eritrea" was given by Italy in 1890. Basically, Eritrea has many similarities with Ethiopia. The nine ethnic groups in Eritrea are also found in Ethiopia. Geographically, Eritrea region is divided into two areas; the Christian highland, which are linguistically and culturally homogenous and low Moslem which are linguistically and culturally heterogonous. The long period of colonialism created traditional differences between the highland and the low land population. However, Eritrea has nine ethnic groups, the government has two administrative languages; Arabic and Tigrinya. Arabic is chosen to represent the Moslem community who live in the low land region (Fuller, 2011).

Religion was introduced in Eritrea during colonial period. Eritrea was ruled by Axum kingdom from $3^{\text {rd }}-4^{\text {th }}$ century $A D$. This kingdom was based upon trade across the Red Sea conducted by Semitic people from Arabia. On the other hand, Christianity was the dominant religion in Axum. Similarly as Islam, Christianity was also introduced by traders throughout the region. Furthermore, the expansion of European power began in $19^{\text {th }}$ century marked by the presence of French and the Italian missionaries, and also the establishment of British consulate in Mossawa. After the reign of European empire, Eritrea faced long period of political conflict with Ethiopia. Eritrea proclaimed its independence in 1958 after the United Nation hold referendum in Eritrea, but Eritrea gained international independence acceptance for its country in 1993 (Dirar, 2007).

The ethnic groups in Eritrea speak nine different languages. Among those languages, it could be classified into three major languages; the Nilotic, the Cushitic, and the Afro-Semitic. The Afro-Semitik language consists of Tigre, Tigrinya, and Rashaida. The Tigre and Tigrinya are the two largest ethnic group in Eritrea. The Eritrean government modified 'the traditional society' through centrally planned social change. One of the policies was on new educational system. Mother tongue was used as the language instruction in primary school. The government expected that by introducing mother tongue in early education, it could instill pride in national and local identity among young generation. In addition, using mother tongue as language at school was very beneficial in preserving minority language and folk tradition (Woldemikael, 2003).

Eritrea is a nation which emphasizes the principle of 'one nation, one land, and many languages' as seen in its language planning. There are two types of language planning. The first type is giving an opportunity to one indigenous language to develop as the language of government, administration, law, education, and commerce, and to establish political and cultural autonomy in the country. The second type of language planning is maintaining national pluralism. By emphasizing the spirit of 'Unity through cultural diversity', the government introduced all indigenous language in the educational system and all governmental and official practices (Heine (1992), William (1996) in Woldemikael, 2003)).

c. Botswana

Botswana is a multilingual and multicultural country which is located in Southern Africa. There are many ethnic groups in Botswana. The main ethnic group 
is called the Tsawana. Botswana is rich with diamond, it gives big contribution for the economics growth. Among the countries in African continents, Botswana is the country whose population are the most infected with AIDS. As a result, Botswana has lower life expectancy, higher infant mortality, higher death rate, and lower population grows rates (Nkosana, 2014).

Before the arrival of the Tsawana, the earliest inhabitants in Botswana are called 'San'. Tswana becomes the dominant ethnic group in Botswana today. Botswana is the British protectorate which got its independence in 1966. Botswana has two main languages; English is the official language and Setswana is the national language. Setswana is the mother tongue of $80 \%$ population in Botswana. As a consequence, the government gives small opportunity for the development of language from other ethnic groups. Kamwendo and Mooko (2006) in Adeyemi (2008) said that Botswana government promoted the homogeneity of the country and tended to focus on the national building. Therefore, the government developed monolithic nation by emphasizing the spirit 'one language, one culture under one flag'.

There are 26 languages spoken in Botswana, but only the Setswana - the majority language - used as the language instruction in the initial education. On the other hand, English is used as the medium of instruction. Botswana adapts transitional bilingual language policy. It means the first language becomes the medium in the initial stage followed by the second language. Furthermore, transitional bilingual education facilitates the students to learn by using two languages. Students used L1 as language instruction in the initial stage, after that L2 is used to teach all subjects and L1 is taught as a subject (Matiki (2006) in Adeyemi (2008)).

The language policy in Botswana gives some negative implications. It gives disadvantage to the people whose mother tongue different from the national language of the country. On other words, many students meet that the language instruction used in their classroom are not the language that they used at home. This phenomenon is usually faced by the minority ethnic groups. The learning process becomes more difficult when teachers and students so not share the same language. In response to this problem, the government does not commit to produce materials in the national language and indigenous language in order to facilitate smooth learning process. In addition, the government also does not train the teachers to teach by using the indigenous language (Mokibelo, 2016).

d. Bangladesh

Bangladesh is one of the poorest countries in the world. The major populations of Bangladesh are called Bengali who comes from different origins. The earliest group who settle in Bangladesh is called Vedda, and then followed by people from Mediterranean who speaks Indo-European languages. Actually Bangli is originated from the lower-caste of Hindus who had converted to Islam. People of Bangladesh are the immigrants from Arab, Persian, and Turkish who moved in $13^{\text {th }}$ century. The rest of the populations are non-Bengalis, they are dominated by the people from Myanmar, they live in the Chittagong Hills Tracts in the southeast area. The other indigenous peoples who live in Bangladesh are Santhal, Khasi, Garo, and Hajang. Santhal live in Southern part of Bangladesh, Khasi live in Sylhet near the border of Assam. Garo and Hajang live in the Northeastern part of the country.

Most of the indigenous languages in Bangladesh are oral only, without their own orthographies, and are used at home and in everyday local community interactions. Many indigenous people, like almost all citizens of Bangladesh, speak 
Bangla. Some indigenous people who have been formally educated through the school system can speak and write Bangla, unlike the illiterate indigenous peoples. The indigenous people use their mother tongues at home at the rate of $80-100 \%$ in addition to another indigenous language besides the mother tongues, and also Bangla (Ahmed et al., 2010; Brightbill et al., 2007; Kim \& Kim, 2008a, 2008b; Rafi, 2006). Very few indigenous languages such as Chakma, Santali, Meitei have their own scripts. An accurate number of speakers of these languages is difficult to provide as the statistics vary according to different sources. Debates prevail as to which script should be used for first-language literacy of the minority indigenous people. The written indigenous languages in Bangladesh mostly have writing systems using Bengali, Devanagari, or Latin scripts (Lewis, 2009). Some indigenous groups who have their own scripts besides the Bengali and Latin scripts, such as the Chakmas, are divided on whether Bengali, Latin or their own scripts should be used in domains such as education or media. Conversely, groups lacking their own scripts, e.g. the Tripuras, are divided over whether Bengali or Latin scripts should be used in these domains. Some groups, such as the Pankoos, Lushai, Khumi, Bawm, do not mind using their existing Latin scripts (Dewan, 2001, p. 11).

The national language of Bangladesh is Bengali (Bangla). It becomes the mother tongue for almost all population in Bangladesh. Bengali has two different styles; Sadhu Bhasa which contains many words derived from Sankrit and Calit Bhasa which become colloquial language and become the standard of informal language in Bangladesh. Bangali has many loanwords from Portuguese, English, Persian, and Hindi. On the other hand, the indigenous ethnic groups have their own language and dialect. The language of indigenous ethnic group is called TibetoBurman Languages, meanwhile English and Indo-European language are also spoken by the people in the society especially in urban center and among educated people.

Currently, Bangla has the status of the national and the major official language of the country used as the medium of instruction, mode of communication, workplace, public meeting and media. The Constitution, however, does not mention anything about the status of either English or the indigenous languages in the country. It does not even recognise the role of English inside the country even though currently the language is considered to offer 'significant economic opportunities for its speakers' and is also 'linked with socioeconomic class' as it is 'used in the home and in many social settings among upper-class families' (Hossain \& Tollefson, 2007, p. 255). In addition, neither the Constitution nor any Bangladeshi law specifically recognises or protects indigenous people and their rights in Bangladesh even though the Constitution prohibits discrimination on the grounds of race, religion, and place of birth under Article 28. Thus, the Constitution plays a crucial role in the status planning for the country's languages.

British ruled over the Indian subcontinent as their colony for nearly two hundred years. They introduced English as the medium for education, administration, and commerce. Learning English achieve special status until the partition of India into Pakistan. The Liberation War in 1971 earned independence for Bangladesh as well as unique status for Bangla that replaced Urdu and English. Furthermore, Bangla Implementation Act in 1987 explained the roles of English in socio-cultural domain, English continued parallel with Bangla as language of instruction and examination. English is taught in primary, secondary, higher education, and tertiary level. However considered as foreign language, English takes a special importance in the national educational policy in Bangladesh. It 
becomes the most important language as academic affairs and job placement, also become a tool for social advancement and economic development. People in Bangladesh often mix English with Bangla in the social discourse. Elite Bangladeshis tend to speak English abruptly in their communication by using code switching and code mixing (Ali, 2013:117-118).

\subsection{Language Use and Identities}

Every nation has the right to its own language. Socioeconomic and political aspects usually become the main reasons underlie the implementation of its national language. There are some countries which use language of colonizers as their national language such as the former Soviet Union, Japan, India, Tanzania, and Pakistan. This section discusses socioeconomic and political factors and its impact toward the national identity.

Russia was well-known as Tsarist Russia Empire in 1900s. It imperialized almost whole parts of the continents includes Poland, Latvia, and Finland. Russia internalized every single aspect in society; (1) All schools subjects taught in Russian, (2) Declaring Russian became the official language, (3) Legal system operated based on Russian system, (4) Language, education, law, religion were placed under the direct control of Russian system. As a consequence, after the dissolution of Soviet Republic, most of the former Soviet countries adapted the system that was implemented since the colonial period including the language.

Similarly, India, Tanzania, and Pakistan also faced long period of colonization. They were colonized by British Empire. The colonizers built educational and political systems in those three countries. In this case, India and Pakistan have the same history since they used to become the same country during the colonization period. British built schools which use British educational model in India. Moreover, British Empire influenced Tanzania in the national ideology. Since Tanzania became capitalist country, there was great advancement of school system. All of schools which were built by the British Empire used English as the language instruction. Furthermore, education brought India, Pakistan, and Tanzania became more advanced countries. They adapted British educational system until they got their independence. Besides educational system, British Empire also influenced India, Pakistan, and Tanzania in the political aspects. British tried to create Indian in blood and English in taste. All officials and public affairs were conducted in English. Also, the British colonials also built educational system in Tanzania to provide low-level employees for government office which fit with colonialist ideology.

Japan also faced long period of colonization. Before America imperialized this country, Japan was ruled by the various ancient empires. Because of the spirit of globalization, Japan opened its harbor for international trade during Kanagawa Regime. As a consequence, Japanese started to leave 'anti-western ideology'. English was used for commerce and education. Japanese government invited native teachers for teaching in schools. Japan began more advanced country in East Asia because of its educational system.

In short, political and socioeconomic interests always underlie the government in determining its national language. On the one hand, they could develop their countries after using the colonizer language because they would be recognized internationally. They would be easily to intermingle with other international countries in the world. On the other hand, it seems they loss their national identity. For instance, Japan diluted the development of indigenous ethnic groups after implementing English as its official language. Japanese government seems ignoring 
the multicultural society which exist in Japan. It also happens in the former Soviet Union where many ethnic groups considered to be neglected by the implementation of Russian language.

Actually we cannot claim the national identity only from one aspect. However language could show the national identity, we have other aspects which also could show our identity as a nation. Japan is one of the developing countries in the world which is well-known because of the advancement of science and technology. Japan could show their national identity by using language and culture. However they use English as official language, they keep preserving Japanese language and its orthography as part of their cultural heritage. Also, Japanese cultures and traditions have proven as the Japanese national identity. Like Japan, India also maintains their traditional custom and culture to show their national identity. However India still struggle with its poverty, the educational system in this country is more advanced than Indonesia due to the adaptation of British educational model. National identity of Indians could be seen from their cultures - clothes, customs, traditions - and also language with its unique orthography.

2.6 Preserving Indigenous Language as National Identity

However it is not stated in the constitution, the use of indigenous language as alternative for development is now accepted in principle throughout Africa. Some African countries discussed in the previous section share something in common. They preserve their indigineous languages and use as language instruction. In fact, this language policy causes some conflicts and problems in its implementation.

Nigeria, Eritrea, and Botswana are multilingual societies. Their populations consist of various ethnic groups. The language policy in all of those three countries advocate multilingualism for the national goals. Their governments proclaim the spirit 'One Nation, One Land, Many Languages'. Their constitution recognize English as official language, and the indigenous language as the regional languages. In fact, this language policy causes some problems and conflicts in the society. The government of Nigeria, Eritrea, and Botswana have not prepared the consequences beyond the language policies. The educational policies in those three countries use English as language instruction in the classroom. Their government believe that this policy could promote local and national identity among young generation. On the other hand, the textbooks which are available for students are written in English. This condition makes the students feel overwhelmed, they should undergo learning process in their mother tongue, but the materials are written in the language that they do not understand well. Actually, the impacts of language policy are not only faced by students. Eritrea is the African country which adapt language shift in the educational system. Teachers face confusion because they should deliver materials in English, the language that they are not familiar with. Similarly, the students also feel frustated because the learning process is conducted in the language that they are not familiar with. In addition, another problem which comes up is the effect of the diversity of the indigenous language. Sometimes, students are confused when the native language used by the teacher in the classroom is different from the language that they speak at home.

On the other hand, different situation faced by Bangladesh. As a country which shares the same historical background with India and Pakistan, Bangladesh faces more conflicts than those two countries. By adapting Bengali as the national language, the government expects that this language policy could represent the existence of various ethnic groups in Bangladesh. Bangladesh faced language conflict due to the existence of three different languages in the society - Bengali, 
English, and Urdu. The status of English declined after the Liberation War in 1971 and Bangla becomes the state of language in Bangladesh. Actually Urdu has become lingua franca since 19th century. Urdu is considered as the important element for Moslem in India. The language conflict is caused by Urdu and Bangla native speakers. The conflicts stick out when native speakers of Urdu refuse making Urdu as lingua franca in India. This language conflict occurs in long period of time.

In short, a country needs lingua franca which can unite ethnic group diversity. If there are many different ethnic groups in one country, choosing one indigenous language might stimulate ethnical conflicts. Since the learning process involves students and teachers, using indigenous language as language instruction in the classroom brings many consequences for the government. The government should train the teachers to teach in different languages, also, the government should prepare the materials written in indigenous language. Therefore, there are sustainability among students, teachers, and learning materials.

\section{CONCLUSION}

Lingua franca has important roles in the society to unite the cultural diversity. Lingua franca is adapted from the dominated language in the colonization era. Therefore, people often regard it as the language of colonizer. The roles of lingua franca in uniting cultural diversity could be seen in several former colonized countries such as The Former Soviet Union, India, Japan, and Pakistan. Lingua Franca becomes language of education, commerce, and legal administration. By adapting lingua Franca does not mean that all of those countries loss their national identities. Appropriate language policies help the native language coexisted in the country together with the lingua franca. On the other hands, some African countries and Bangladesh face language and ethnical conflicts. The ethnic domination and the lack of government control over language policy are the main sources of the conflicts. Therefore, preserving indigenous language needs language policy to regulate the language diversity.

\section{REFERENCES}

Adejimola, Amusegham Sunday. (2010). Language Policy Provisions and Curriculum Issues: The Challenge for Secondary School in Nigeria. USChina Education Review Vol 7 No.11 pp 53-61.

Adeyemi, Deborah A. (2008). Bilingual Education: Meeting the Challenges of Diversity in Botswana. Nordic Journal of African Studies. Vol 17.No.1. pp 20-33.

Ali, Mohammad Arshad. (2013). Language Policy and Planning for Bangla in the Current Context of Bangladesh: Possibilities and Constraints. Prime University Journal. Vol.7 No.2. pp 113-137.

Armenui, Minasyan. (2014). Language Policy, National Identity, and Politics. European Scientific Journal Vol.2 pp 273-277

Canagarajah, A.Suresh. (2006). Negotiating The Local in English as a Lingua Franca. Annual Review Applied Linguistics. Vol.26 pp 197-218.

Danladi, Shaibu Sunday. (2013). Language Policy: Nigeria and the Role of English Language in the 21st Century. European Scientific Journal. Vol.9 No.17 pp 1-21. 
Dirar, Uoldelul Chelati. (2007). Colonialism and the Construction of National Identities: The Case of Eritrea. Journal of Eastern African Studies Vol $1: 2$ pp 256-276.

Gogfrey, Telli. (2014). The Language Instrcution Issue in Tanzania: Pertinent Determining Factors and Perceptions of Education Stakeholders. Journal of Languages and Cultures Vol.5 No.1 pp 9-16

Hatori, Reiko. (2005). A Policy on Language Education in Japan: Beyond Nationalism and Linguicism. Second Language Studies. Vol. 23 No 2. pp 45-69.

Idris, Syahrir. (2014). Language Policy and the Construction of National and Ethnic Identities in Indonesia. US-China Education Review. Vol.4, No.10 pp 691-705

Mokibelo, Eureka. (2016). Transition from Swetswana to English: A Policy Dillema. Journal of Language Teaching and Research. Vol.7 No.4 pp 665-674

Ngowi, Honest Prosper. (2009). Economic Development and Change in Tanzania since Independence: The Political Leadership Factor. African Journal of Political Science and International Relation. Vol.3 No.4 pp 259-267.

Nkosana, Leonard Ben Mwalimu. (2014). Mother-Tongue Education in Botswana. International Journal of Scientific Research in Education. Vol.7 No.1 pp 45-54.

Ogunmodimu, Morakinyo. (2015). Language Policy in Nigeria: Problems, Prospects, and Perspectives. International Journal on Humanities and Social Science. Vol. 5 No.9 pp 154-160.

Rahman, Tania. (2010). A Multilingual Language-in-Education Policy for Indigenous Minority in Bangladesh: Challenges and Possibilities. Current Issues in Language Planning Vol. 11. No. 4. pp 341-359.

Subhash. (2013). Three Language Education Formula in Multilingual India: Problems and Prospects. International Journal Educational Research Vol 1. Issue 4. Pp 150-158.

Swilla, Imani N. (2009). Language Instruction in Tanzania: Contradiction between Ideology, Policy, and Implementation. African Study Monograph. Vol.30 No.1 pp 1-14

Vijayalakshmi, M \& Manchi Sarat Babu. (2014). A Brief History of English Language Teaching in India. International Journal of Research and Scientific Publication. Volume 4. Issue 5. Pp 1-4.

Woldemikel, Tekle M. (2003). Language, Education, and Public Policy in Eritrea. African Studies Review. Vol 4. No.1 pp 117-136 